NBER WORKING PAPER SERIES

\title{
THREE CURRENT ACCOUNT BALANCES: A SEMI-STRUCTURALIST" INTERPRETATION
}

\author{
Menzie D. Chinn \\ Jaewoo Lee \\ Working Paper 11853 \\ http://www.nber.org/papers/w11853
NATIONAL BUREAU OF ECONOMIC RESEARCH
1050 Massachusetts Avenue
Cambridge, MA 02138
December 2005

Chinn: Department of Economics, University of Wisconsin, 1180 Observatory Drive, .Madison, WI 53706. Tel 608262 7397. Fax: 608262 2033. Email: mchinn@lafollette.wisc.edu. ** Lee: Research Department, IMF, 700 19th Street, NW, Washington, DC 20431. Tel: 202623 7331. Fax: 202589 7331. Email: jlee3@imf.org. The views expressed in this paper are those of the authors and should not be attributed to the NBER, the International Monetary Fund, its Executive Board, or its management.

(C2005 by Menzie D. Chinn and Jaewoo Lee. All rights reserved. Short sections of text, not to exceed two paragraphs, may be quoted without explicit permission provided that full credit, including $\odot$ notice, is given to the source. 
Three Current Account Balances: A "Semi-Structuralist” Interpretation

Menzie D. Chinn and Jaewoo Lee

NBER Working Paper No. 11853

December 2005

JEL No. F31, F41

\begin{abstract}
Three large current account imbalances - one deficit (the United States) and two surpluses (Japan and the Euro area) - are subjected to a minimalist structural interpretation. Though simple, this interpretation enables us to assess how much of each of the imbalances require a real exchange rate adjustment. According to the estimates, a large part of the U.S. current account deficit (nearly 2 percentage points of the 2004 deficit of $51 / 2$ percent of GDP) will undergo an adjustment process that involves real depreciation in its exchange rate. For Japan, a little more than 1 percentage point (of GDP) of the current account surplus is found to require an exchange rate movement (real appreciation) as the surpluses adjust down. For the Euro area, less than half a percentage point of its current account surplus is found to require an adjustment via real appreciation.

Menzie D. Chinn

Department of Economics

University of Wisconsin

1180 Observatory Drive

Madison, WI 53706

and NBER

mchinn@lafollette.wisc.edu

Jaewoo Lee

Research Department

International Monetary Fund

jlee3@imf.org
\end{abstract}




\section{INTRODUCTION}

There has been a vigorous debate regarding the origin and implications of the current account imbalances that have become ever more prominent over the past couple of years. With the debate showing no sign of abatement, now seems a good time to impose a little "structure” upon the discussion. We say "a little” because in this paper, we follow a middle road, aiming to avoid the amorphous argument over whether there is a global savings glut or revived Bretton Woods arrangement, and at the same time provide a differing perspective from those gleaned from the new generation of dynamic stochastic general equilibrium (DSGE) models.

To provide a little context, consider the savings glut/investment drought perspective most closely associated with Bernanke (2005). ${ }^{1}$ In his view, the US current account deficit is the outcome of deficient savings in the U.S., excess savings relative to investment in East Asia and Europe, and the relatively higher rate of return on U.S. assets. Setting aside the dissonant fact that U.S. private sector savings in 2004 are much like they were in 2000, the argument achieves some amorphousness by virtue of the fact that "normal" - which is necessary to defining what is excess and what is deficient - is never defined, except by virtue of arbitrarily selected reference periods.

On another front of the debate is the disagreement between the new generation of macroeconomic models, epitomized by the Fed's Sigma model and the IMF's Global

\footnotetext{
${ }^{1}$ Related papers include Clarida (2004, 2005) and Hubbard (2005). For an econometric critique, see Chinn and Ito (2005). On a somewhat different but related note, Gourinchas and Rey (2005) and Blanchard et al. (2005) both emphasized the role that the foreign interest in the U.S. assets played in the current developments and prospects of the U.S. current account deficit.
} 
Economic Model. ${ }^{2}$ Both of these models typify an approach that incorporates enormous amounts of structure and internal consistency. Yet, despite the common theoretical ancestry of these models, they disagree substantially about the impact of fiscal policy on the accumulation of external debt, as well as the impact of fiscal policy on the current account. In part, these differences are driven by differences in the behavioral aspects of the models, and in part driven by the differing assumptions used in conducting the simulations.

Yet another view on the likely evolution of imbalances has been provided through correlations viewed through the prism of event studies. Careful studies of this nature have been conducted by Croke et al. (2005), Freund and Warnock (2005), and Galati and Debelle (2005). They examine previous current account deficit reductions in developed economies. While useful, the event study approach aggregates and averages the shocks both within and across episodes. ${ }^{3}$

For these reasons, we believe that it would be a profitable enterprise to apply a method that, in principle, can say something about the evolution of key current account imbalances and real values of currencies. In this regard our approach can answer two central questions. First, how "sustainable” is the U.S. current account deficit, in the sense that it has a persistent component. Second, in the adjustment of the current account to its long run value, how much must the dollar adjust.

\footnotetext{
${ }^{2}$ Greenspan (2005) and Ferguson (2005) referred to simulations of this model in their assessment of the origins of the U.S. current account deficit. See Erceg et al. (2005a,b). For GEM, see Laxton et al. (2005).

${ }^{3}$ There are also a set of time series models invoking threshold effects; see Clarida et al. (2005).
} 
It is important to note that the results of our approach can be interpreted in a number of ways. Movements in the real exchange rate can be interpreted as consistent with the traditional view of currency values inducing expenditure switching. But, for those concerned with intellectual rigor, our approach is entirely consistent with the Obstfeld and Rogoff (2004) approach, wherein exchange rate adjustment is jointly determined with tradable goods consumption reduction. Whereas they assume an exogenously imposed need for a reduction of the U.S. current account balance, we quantify how much of the U.S. imbalance will be eliminated, and simultaneously, how much the dollar will decline, given historically observed responses to shocks. Nor do we consider our approach as a substitute for the DSGE simulation or the event study approach. Rather, our study can be considered complementary to approaches that rely upon cross-country evidence, in contrast to our purely time series methodology.

Without claiming full generality, this paper adopts a parsimonious method to decompose shocks in a manner relevant to the current debate. The role of the exchange rate being a point of contention, shocks are decomposed according to their long-run effect on the real exchange rate. In particular, Lee and Chinn (2002) found that the shocks with only temporary exchange rate effects brought about a negative correlation between the current account and the real exchange rate—current account improves as the exchange rate depreciates—while the shocks with permanent exchange rate effects did not necessarily bring about such a negative correlation. Then, to the extent that some of the current account deficit of the United States is driven by temporary shocks, its correction will be accompanied by a depreciation in the real exchange rate. 
Applying the framework to the current account imbalances of three largest economies—a deficit in the United States and surpluses in Japan and the Euro area— we find that a substantial part (nearly 2 percentage points of GDP) of the U.S. current account deficit in 2003 and 2004 is attributable to shocks that have only temporary effects on the real exchange rate. That is, the correction of that part of the U.S. current account deficit will go hand in hand with a depreciation of the U.S. real exchange rate. For Japan and the Euro area, a much smaller part of their current account surpluses in 2004 are found to be driven by temporary shocks.

The rest of this paper is organized as follows. The next section discusses conceptual framework of this note, and section III reports the estimation results. Section IV discusses the implication on the forthcoming adjustment on the basis of historical decomposition. Section V concludes.

\section{ECONOMETRIC FRAMEWORK}

To explore the role of the exchange rate in the recent developments in the current account, we employ a statistical methodology to decompose the source of current account developments according to their long-term effect on the real exchange rate. Macroeconomic shocks that sway current account balances will also affect the real exchange rate. Some will have long-run effects while others have only temporary effects. As will be shown in this section, the shocks that have only temporary effects on the real exchange rate are exactly what motivate the widely held perception that exchange rate depreciates over the medium term when the current account deteriorates (a perception that is accurate). 
We decompose shocks into two types by adopting the econometric identification scheme of Blanchard and Quah (1989). One of the two fundamental shocks is postulated to have no long-term effect on the real exchange rate. The methodology can be summarized by the following bi-variate VAR, estimated for the current account $\left(c a_{t}\right)$ and the first-differenced real exchange rate $\left(\Delta q_{t}\right)$.

$$
\left[\begin{array}{c}
c a_{t} \\
\Delta q_{t}
\end{array}\right]=B(L)\left[\begin{array}{c}
c a_{t} \\
\Delta q_{t}
\end{array}\right]+\left[\begin{array}{c}
\eta_{t}^{c a} \\
\eta_{t}^{q}
\end{array}\right]=B(L)\left[\begin{array}{c}
c a_{t} \\
\Delta q_{t}
\end{array}\right]+B(0)\left[\begin{array}{c}
\varepsilon_{t}^{T} \\
\varepsilon_{t}^{P}
\end{array}\right],
$$

where country-specific temporary shocks are denoted as $\varepsilon_{t}^{T}$, and permanent shocks as $\varepsilon_{t}^{P}$. When $\varepsilon_{t}$ denotes the vector of temporary and permanent shocks, the following standard assumptions are made: $E\left(\varepsilon_{t}\right)=0, E\left(\varepsilon_{t} \varepsilon_{t}^{\prime}\right)=I$, and $E\left(\varepsilon_{t} \varepsilon_{s}^{\prime}\right)=0$ when $t \neq s$.

In a conventional VAR analysis, system (1) will be identified by assuming that $B(0)$ is a lower triangular matrix. It amounts to assuming that the real exchange rate innovation has no contemporaneous effect on the current account, an assumption that is at odds with many theoretical models.

In contrast, the Blanchard and Quah approach enables one to identify the system on the basis of a criterion that is consistent with a wide spectrum of intertemporal open macro models. It is assumed that temporary shocks have no long-run effect on the exchange rate, regardless of other characteristics of underlying shocks. Unlike the identification obtained by Choleski factorization that assumes a lower triangular $B(0)$, the temporary and permanent shocks identified here should not necessarily be interpreted as shocks to the exchange rate and current account, respectively. Estimated innovations to 
the exchange rate and current account $\left(\eta_{t}\right)$ are both linear combinations of temporary and permanent shocks, because the off-diagonal elements of matrix $B(0)$ are non-zero.

In an earlier paper examining the G7 countries, we found that the temporary and permanent shocks carry different relative importance for current account balances and exchange rates, and moreover that they induce different correlations between current account balances and exchange rates. In response to a temporary shock, the current account balance improves when the real exchange rate depreciates. In response to a permanent shock, however, the current account balance improves at the same time as the real exchange rate appreciates. This has clear implications for the current debate on the role of the exchange rate. To the extent that today's current account imbalances are caused by temporary shocks, a real dollar depreciation is imminent.

\section{DATA AND ESTIMATION RESULtS}

\subsection{Data}

The current account and real exchange rate data are largely drawn from the International Financial Statistics database, at the quarterly frequency, except for the seasonally adjusted U.S. current account that was obtained from the BEA. For all three economies, the real effective exchange rates (based on CPI) are available since the first quarter of 1980. The current account data are available until 2004 for the United States and the Euro area and until 2003Q3 for Japan. The U.S. current account balances were adjusted for the Gulf War transfers of the early 1990s. In the econometric estimation, the current account balance is measured as the ratio of its dollar value to the dollar- 
denominated nominal GDP. The real exchange rate is the first-differenced log of the real effective exchange rate index based on the consumer price index. ${ }^{4}$

\subsection{Estimating the VAR and Impulse Responses}

The VAR system was estimated with two lags for all three economies, based on standard criteria (Akaike information criterion and Schwartz criterion). However, a shorter sample ending in 2001Q4 was used for the United States, to avoid the post-2001 period which suggests a substantial change in econometric relationship. Starting in 2002Q1, the real effective exchange rate of the United States began to depreciate, while its current account deficit also kept on rising. The estimation over the full sample resulted in impulse response functions that were opposite to those obtained for the U.S. using any sample period that excludes 2004, and opposite to those obtained for other economies with any sample period (typical impulse responses are discussed in the next paragraph). ${ }^{5}$ Though not a rigorous test, we view this result as suggesting an anomaly in the external developments of the U.S. in recent years. Consequently, we used data preceding this period.

Estimation results are reported in Table 1. In general they accord with one's priors. It is more difficult to explain movements in real exchange rates than in current account balances. The $R^{2}$ s for the exchange rate change equations range from 0.10 to 0.13, while those for the current account balance take on values from 0.72 to 0.94 . First

\footnotetext{
${ }^{4}$ Greater detail is contained in the Data Appendix.

${ }^{5}$ While the econometric results are sensitive to the inclusion of the 2004 data for the U.S., the results for Japan and the Euro area are little affected as the end point of the sample is varied from 2002 to 2004.
} 
differences of the real exchange rate exhibit some serial correlation, with the coefficient on the lagged difference ranging from 0.22 to 0.31 . In contrast, the current account balance exhibits substantial persistence, with the coefficient on the first lag taking on values as high as 0.87 (for the United States).

Applying structural decomposition to examine the effects of two different types of shocks, temporary versus permanent shocks are found to bring about opposite correlations between the real exchange rate and the current account. The impulseresponses in Figures 1 to 3 show that for all three economies, a real depreciation accompanies an improvement in the current account under the temporary shocks. This corresponds to the oft-mentioned expenditure-switching effect on the current account of exchange rate changes. In contrast, for permanent shocks, a real appreciation goes hand in hand with an improvement in the current account, contradicting conventional wisdom regarding the current account balance - exchange rate relationship. It should emphasized that the identification criterion for temporary and permanent shocks impose no a priori restrictions on the signs of these correlations.

The economic interpretation of the permanent and temporary shocks, discussed further in our previous paper (Lee and Chinn, 2002), can be summarized as follows. Temporary shocks find an easy candidate in monetary shocks. These are often viewed as having only a temporary effects on the real exchange rate, excepting long run net-wealth effects which are quantitatively tiny. Permanent shocks are more difficult to pin down. Typically, permanent shocks are associated with productivity innovations; however, this is often thought of as inducing a negative correlation between the current account and the exchange rate. We prefer the interpretation of the permanent shock as a preference shock 
in favor of home exports, which would have a long-run effect on the real exchange rate, while inducing a positive comovement between the current account and the real exchange rate. ${ }^{6}$ It might be more useful to think of a negative value of this shock - a shock against home exports. One could interpret a "surprise” in government spending as a sort of negative preference shock, since government spending is likely to divert exportables back to home consumption.

Regardless of their economic interpretation, what matters foremost for our current purpose is the existence of these two types of shocks and the different correlations between the current account and the exchange rate induced by these two shocks. It is the temporary shocks that induce the usual negative correlation between the current account and the real exchange rate.

How do these estimated impulse response functions compare to our previous estimates? Since for the sample has changed somewhat - it is expanded by up to four years - one might expect some changes. For the U.S. and Japan, the changes are relatively minor. For the euro area that was not analyzed in our previous study, we compare it with the previous results for several member countries. We find the temporary component has an initial impact on the current account about three times as large as it did for Germany, but only about twice as large as for Italy. The impact of the permanent component is about the same as in Germany or France.

\footnotetext{
${ }^{6}$ Abstracting away from temporary shocks, Blanchard et al. (2005) provides an analysis of preference shocks that have permanent effects on the real exchange rate. Consistent with our interpretation, a preference shock in favor of foreign exports generates a real depreciation and current account deficit along the adjustment path.
} 


\section{History AND Prospects}

Given the estimates of the structural matrix - $B(0)$ matrix in equation (1) - the estimated shocks to the current account and the real exchange rates can be decomposed into temporary and permanent shocks. By tracking their effects using the estimated coefficients, we can uncover the contribution of temporary and permanent shocks to the past movements in the current account and the real exchange rate. Subject to the initial conditions, which are the prevailing values of the current account and the real exchange rate at the beginning of the sample (in 1980), this historical decomposition brings to light how much of the current account imbalances are attributable to temporary and permanent shocks.

One thing we know about the current account imbalance due to temporary shocks is that its adjustment (e.g. improvement in the case of the United States) will entail a movement in the real exchange rate in the opposite direction (thus a real U.S. dollar depreciation). The same temporary shocks will reverse its own effect on the exchange rate, for they have no permanent effects on the real exchange rate. That is, the portion of the current account due to temporary shocks is the amount of current account imbalance that will be corrected through a real exchange rate adjustment in the direction consistent with the conventional wisdom.

Permanent shocks, on the other hand, do not lead to a usual comovement in the current account and the exchange rate. Given the stationary nature of the current account, the effect of permanent shocks to the current account will decay over time. But this 
process will not be accompanied by a movement in the exchange rate in any particular direction, because the permanent shocks will have a lasting effect on the exchange rate and no further adjustment in a particular direction is necessary.

The historical decomposition of the U.S. current account and the real exchange rate is presented in Figure 4. The upper panel shows the current account in percent of GDP since 1983, the portion attributable to the initial values and deterministic factors (constant terms in the estimated VAR), and the portion attributable to these and permanent shocks (named "non-transitory component”). The lower panel shows the real exchange rate index and the portion attributable to comparable sources of shockspermanent shocks, deterministic factors, and initial values.

The role of temporary shocks in the current account deficit and the exchange rate is strikingly large in the United States. Almost a half of the current account deficit since 2000 is attributed to temporary shocks, suggesting that its correction will entail a depreciation in the real exchange rate. After the correction of the deficit due to temporary shocks, there still remains a small deficit due to permanent shocks. This deficit will also decline, to bring the current account close to the deterministic part, but without necessarily involving exchange rate adjustment.

Turning to the exchange rate, a large gap opened between the actual exchange rate and its long-term component during the last several years. The gap had peaked in 2002 and has since narrowed slightly. Nevertheless, in 2004, a gap of more than 10 percent exists between the actual real exchange rate and its long-term component driven by nontransitory shocks. While the real depreciation of the past two years has brought the value 
of the U.S. dollar down close to its 1997-98 value -- when the actual rate matched the long-term component of the exchange rate -- the long-term component itself has declined further since then, so that the gap between the actual and long run equilibrium has remained largely unchanged.

How do these results relate to the ongoing debate? First, the exchange rate result has something of the flavor of the Permanent Equilibrium Exchange Rate concept, in which the permanent component is extracted by virtue of a transitory-permanent decomposition; however, in this case, the decomposition is bivariate in nature. ${ }^{7}$ Thus, in the sense of deviating from an "equilibrium value”, the dollar remains overvalued.

The non-transitory component also seems quite large in absolute value, at -4.14 percent of GDP compared to a recorded value for 2004 of -5.68 percent of GDP. What this indicates is that exchange rate depreciation associated with the conventional adjustment process will not return the current account deficit to something less than 4 percent of GDP by itself. A further reduction of the current account deficit will follow as the effect of permanent shocks on the current account wanes. That part of adjustment, however, does not necessarily involve a further exchange rate realignment, according to the impulse-response analysis discussed earlier.

The question of how far the current account deficit will decline can be answered by our estimate of the deterministic component of the current account - essentially that part of the historical decomposition arising from initial values and estimated constants in

\footnotetext{
${ }^{7}$ A closely related approach is in MacDonald and Swagel (2000). See the discussion in Driver and Westaway (2004).
} 
the VARs. The estimate suggests that current account deficit will decline to about 3.0 percent of GDP when various shocks work their ways out. This answer can also inform the debate regarding the "sustainable current account.” Here, we take the view that a current account deficit of about 3.0 percent is "sustainable" in the sense that - based upon historical correlations - the deficit will revert to this value.

This conclusion may be surprising to those who believe that that a zero current account deficit must be achieved eventually. However, it is important to note that, with the economy growing over the long term, a negative current account balance and stable debt to GDP ratio are compatible. Furthermore, given the fact that the United States has earned more on its assets abroad than foreigners have earned on the assets they own in the U.S., there is extra “wiggle room” for running a deficit. Kouparitsas (2005) has calculated the sustainable net exports deficit at 1.4 percent of GDP. Different assumptions lead to slightly higher numbers (although none are near a current account deficit of 6 percent of GDP, which is predicted for 2005). ${ }^{8}$

For Japan and the Euro area, a large part of the short-run movement in the current account is attributed to temporary shocks while the big medium-term swings in the current account appear to be driven by permanent shocks. In both economies, temporary components account for a small part of current account surpluses in 2004. The correction of these temporary-shock-driven surpluses will entail some appreciation in their real exchange rates. Interestingly, however, the magnitude of the implied appreciations is quite small.

${ }^{8}$ IMF (2005) forecasts 6.1\%, while the Economist (October 1-7, 2005) survey of economists indicates $6.3 \%$. 
This reading is confirmed by the lower-panel figures of the exchange rate. While the bulk of the exchange rate movement in both Japan and the Euro area is attributed to permanent shocks, temporary shocks are found to have played a bigger role in the movement of Japan's real exchange rate over the past two years. Without the contribution of temporary shocks, the real value of the yen would have been higher than its observed value.

\section{CONCLUSION}

Speculation abounds on the likely path of the U.S. exchange rate, given the unprecedented magnitude of the current account deficit. In the discussion of "global rebalancing”, the potential counterparts in the adjustment of the U.S. current account deficit, the surpluses of two largest economies (Japan and the Euro area) have also attracted much attention. In this paper, we have attempted to impose some structure upon the discussion of what is a normal current account and exchange rate level, for the three key economies.

By applying a simple identification criterion that decomposes the shocks to those that do not have a long-run effect on the real exchange rate (termed temporary shocks) and those that do (termed permanent shocks), the portion of the current account that will adjust via the conventional real exchange rate channel was estimated. The U.S. current account imbalances recorded for 2004 predict a further dollar decline of nearly 20 percent, conditional upon the shocks already observed. Hence, despite the dollar's decline since 2002, the U.S. currency appears destined for a further real depreciation, although 
interestingly, the total decline is less than estimates obtained in other studies (e.g., Obstfeld and Rogoff, 2004). In a striking contrast, an appreciation of a much smaller magnitude is anticipated for Japan and the Euro area. This might reflect the fact that a large part of the U.S. current account deficit is incurred vis-à-vis the other countries not included in our analysis.

Obviously, what we have recounted above should not be construed as forecasts of the current account or the exchange rate of these three economies. This is because the projections into the future are conditional upon the shocks already observed (and recall, by definition the shocks are unpredictable). In addition, it is important to recall that our estimates of the non-transitory components of the current account and the exchange rate are merely estimates-and that considerable uncertainty circumscribes each of these estimates.

Interestingly, those who argue that the past three years of U.S. economic behavior has been aberrant would find confirmation in our results, as we were unable to model the 2002-04 period in a satisfactory manner. We are agnostic on whether this has been caused by a "global savings glut”. However, to the extent that we are able to model the U.S. current account balance and dollar behavior over the period up to end-2001, we do not view this phenomenon as one that has explained the current account deficit over the entire post-East Asian crisis period. Rather it appears to be of fairly recent origin, and hence may prove less durable than some commentators have conjectured.

Finally, we note two limitations of the analysis we have undertaken. The first limitation is that we do not allow for interactions between the economies, at least directly. 
The statistical analysis of the U.S. economy was conducted implicitly viewing the world through a two-country model; then the process was repeated for Japan and the Euro area.

A second, and more important, limitation is that the analysis is predicated upon the future looking like the past. Yet, by virtue of the sheer absolute magnitude of presentday imbalances, we are in uncharted territory. Of course, that is a limitation shared by all the modes of analysis currently being used. 


\section{REFERENCES}

Bayoumi, Tamim, Jaewoo Lee, and Sarma Jayanthi, 2005, "New Rates from New Weights,” IMF Working Papers No. 05/99 (Washington, D.C.: IMF, May).

Bernanke, Ben, 2005, “Remarks at the Homer Jones Lecture.” St. Louis, Missouri, April 14, 2005.

Blanchard, Olivier, Francesco Giavazzi, and Filipa Sa, 2005, “The U.S. Current Account and the Dollar,” NBER Working Papers No. 11137 (February).

Blanchard, Olivier, and Daniel Quah, 1989. The Dynamic Effects of Aggregate Demand and Supply Disturbances. American Economic Review 79(4), 655-673.

Chinn, Menzie and Eswar Prasad, 2003, "Medium-Term Determinants of Current Accounts in Industrial and Developing Countries: An Empirical Exploration,” Journal of International Economics 59(1), 47-76.

Chinn, Menzie and Hiro Ito, 2005, “Current Account Balances, Financial Development and Institutions: Assaying the World 'Savings Glut',” NBER Working Papers No. 11781 (November).

Clarida, Richard, 2004. “Some Thoughts on Exchange Rate Protectionism.” CATO Journal 25(1).

Clarida, Richard, 2005. "Some Thoughts on 'The Sustainability and Adjustment of Global Current Account Imbalances.”” Presentation at the Council on Foreign Relations, March 28, 2005.

Clarida, Richard, Manuela Goretti, and Mark Taylor, 2005. “Are There Thresholds of Current Account Adjustment in the G-7?” Paper presented at NBER conference, “G-7 Current Account Imbalances: Sustainability and Adjustment,” Newport, June 1-2, 2005.

Clarida, R., and J. Gali, 1994. Sources of Real Exchange-Rate Fluctuations: How Important are Nominal Shocks? Carnegie-Rochester Conference Series on Public Policy 41, 1-56.

Croke, H., S.B. Kamin and S. Leduc, 2005, Financial Market Developments and Economic Activity during Current Account Adjustments in Industrial Economies, International Finance Discussion Papers No. 827 (Washington, DC: Board of Governors of the Federal Reserve System, April) 
Debelle, Guy and Gabriele Galati, 2005, "Current Account Adjustment and Capital Flows.” Bank for International Settlements Working Papers No. 169 (Basel: Bank for International Settlements)

Driver, Rebecca and Peter Westaway, 2004, "Concepts of Equilibrium Exchange Rates," Bank of England Working Papers No. 248.

Erceg, Christopher, Luca Guerrieri, and Christopher Gust, 2005, "Expansionary Fiscal Shocks and the Trade Deficit,” International Finance Discussion Papers No. 825 (Washington, DC: Board of Governors of the Federal Reserve System, January (a)).

Erceg, Christopher, Luca Guerrieri, and Christopher Gust, 2005, “SIGMA: A New Open Economy Model for Policy Analysis,” International Finance Discussion Papers No. 835 (Washington, DC: Board of Governors of the Federal Reserve System, July (b)).

Fagan, Gabriel, Jérôme Henry, and Ricardo Mestre, 2001, “An Area-wide Model (AWM) for the euro area,” ECB Working Papers No. 42: (Frankfurt: ECB, January).

Faruqee, Hamid, Douglas Laxton, Dirk Muir, and Paolo Pesenti, 2005, "Current Accounts and Global Rebalancing in a Multi-Country Simulation Model.” Paper presented at the NBER conference, "G-7 Current Account Imbalances: Sustainability and Adjustment,” Newport, June 1-2.

Faust, J., and E.M. Leeper, 1997, "When Do Long-Run Identifying Restrictions Give Reliable Results?” Journal of Business and Economic Statistics 15(3), 345-53.

Freund, Caroline and Frank Warnock, 2005, "Current Account Deficits in Industrial Countries: The Bigger They Are, The Harder They Fall?” Paper presented at the NBER conference, "G-7 Current Account Imbalances: Sustainability and Adjustment, Newport, June 1-2.

Gourinchas, Pierre-Olivier and Helene Rey, 2005, "From World Banker to World Venture Capitalist: The U.S. External Adjustment and the Exorbitant Privilege.” Paper presented at the NBER conference, "G-7 Current Account Imbalances: Sustainability and Adjustment,” Newport, June 1-2.

Greenspan, Alan, 2005, “Current Account,” Presentation at Advancing Enterprise 2005 Conference, London, February 4, 2005.

Hubbard, R. Glenn, 2005, “A Paradox of Interest.” Wall Street Journal, June 23, p. A12.

IMF, 2005, World Economic Outlook (Washington, DC IMF, September). 
Kouparitsas, Michael, 2005, “Is the U.S. Current Account Sustainable?” Chicago Fed Letter No. 215 (June).

Krugman, Paul, 1991. “Introduction,” in: Bergsten, C. F. (Eds.), International Adjustment and Financing: The Lessons of 1985-1991, Institute for International Economics, Washington, D.C., pp. 3-12.

MacDonald, Ronald and Swagel, Phillip, 2000. "Real exchange rates and the business cycle,” mimeo (Washington, DC: IMF).

Lee, Jaewoo, and Menzie D. Chinn, 2002, “Current Account and Real Exchange Rate Dynamics in the G7 Countries,” IMF Working Paper No. 02/120 (forthcoming in Journal of International Money and Finance).

Obstfeld, Maurice, and Kenneth Rogoff, 1996, Foundations of International Macroeconomics. MIT Press, Cambridge, MA.

Obstfeld, Maurice, and Kenneth Rogoff, 2004, “The Unsustainable US Current Account Position Revisited,” NBER Working Papers No. 10869. 


\section{Data Appendix}

Real Exchange Rates: CPI deflated trade weighed indices (series rec), drawn from IMF, International Financial Statistics. See Bayoumi, Lee and Jayanthi (2005) for description of index characteristics.

Current account balances: Dollar amounts, drawn from IMF, International Financial Statistics, for U.S and Japan. The U.S. current account balance is obtained from the BEA and adjusted to omit the effect of Gulf War transfers, using figures reported in various issues of Bureau of Economic Analysis’s Survey of Current Business. The euro area current account balance in euro is drawn from the Area Wide Model (AWM) database described in Fagan et al. (2001), located on the Euro Area Business Cycle Network website (http://www.eabcn.org/data/awm/index.htm). In all cases, current account balances are normalized by GDP. 
Table 1. Vector Autoregression Estimates

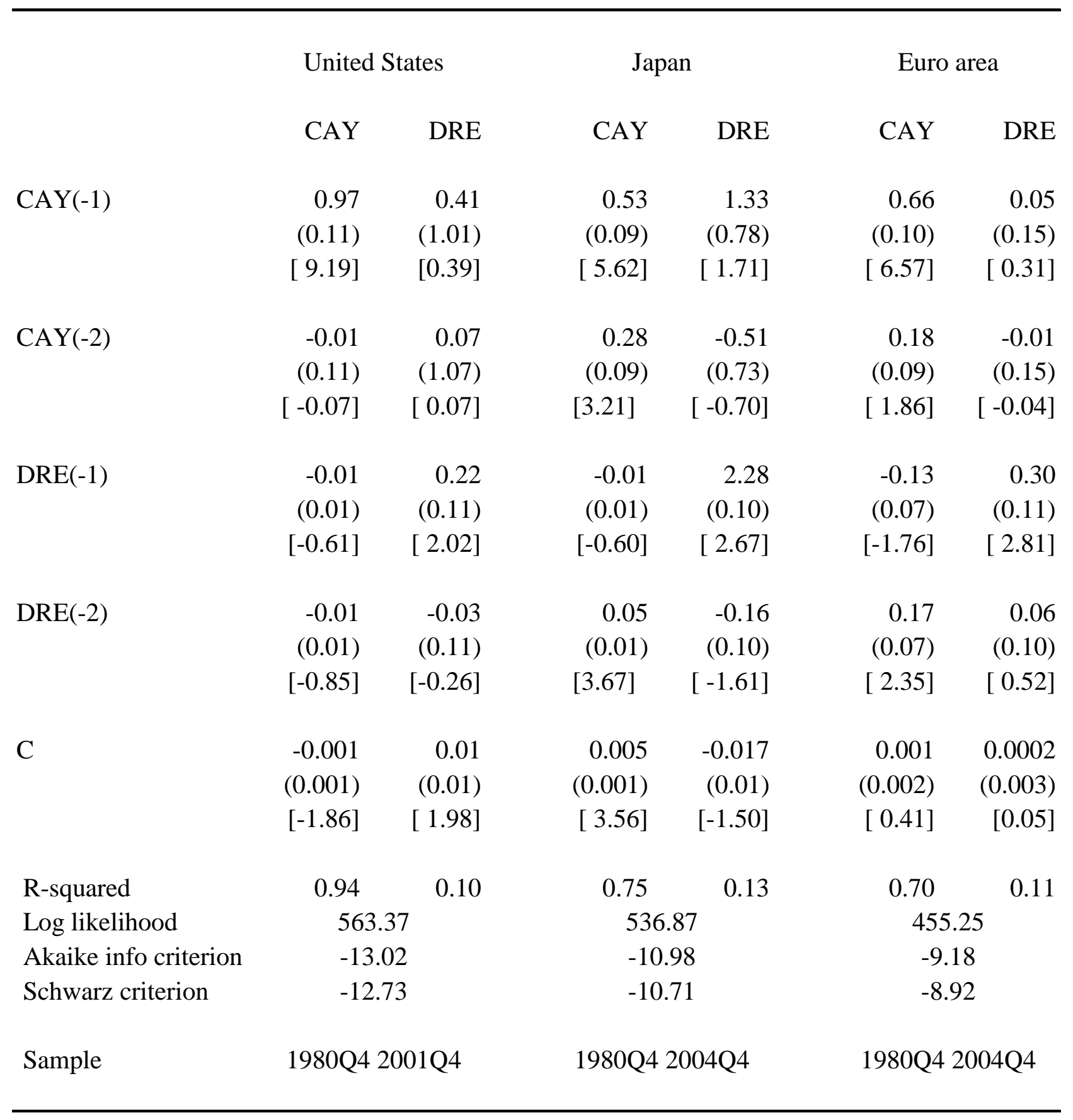

Standard errors in ( ) \& t-statistics in [ ] 
Figure 1. USA: Impulse Responses
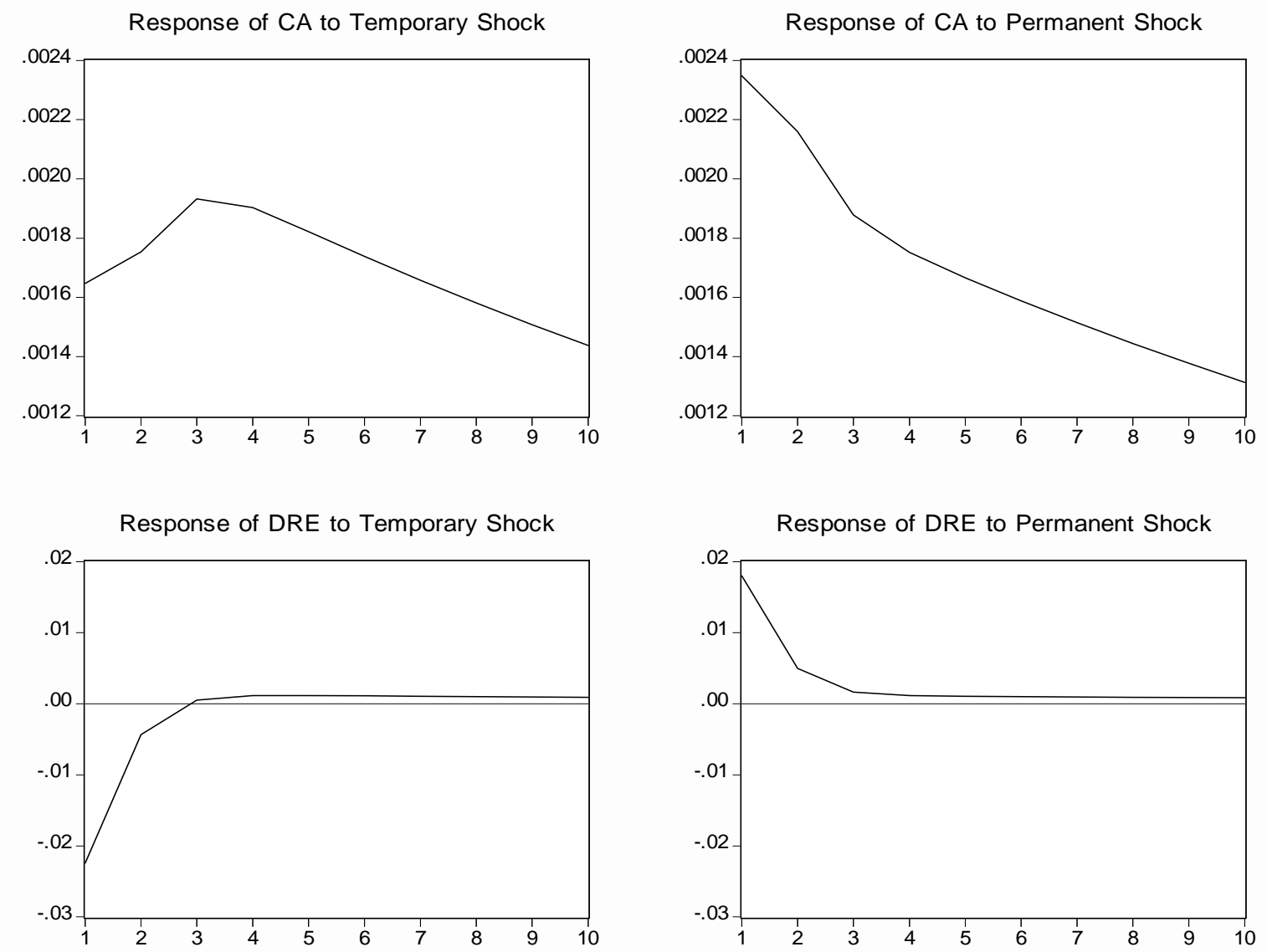
Figure 2. Japan: Impulse Responses
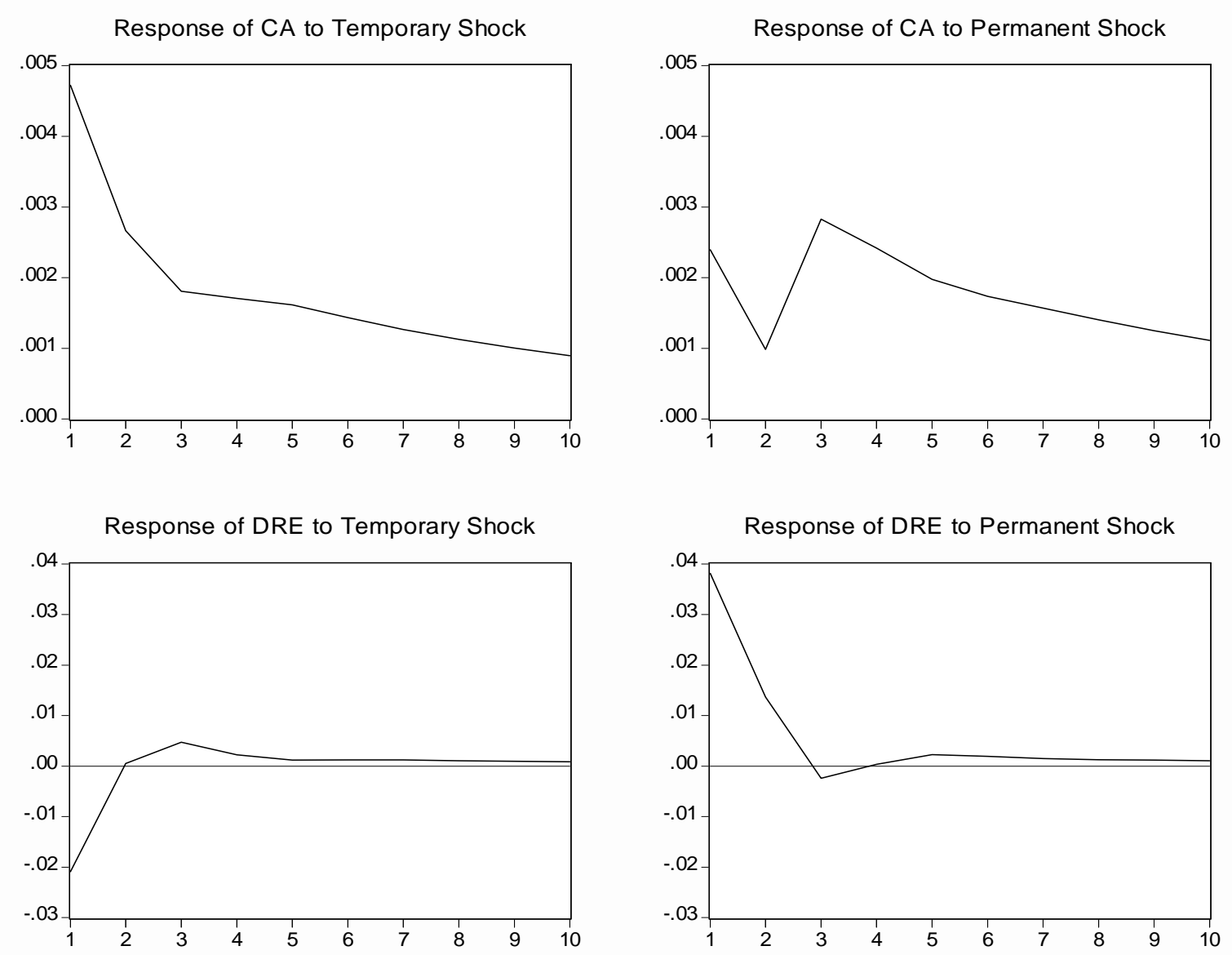
Figure 3. Euro Area: Impulse Responses
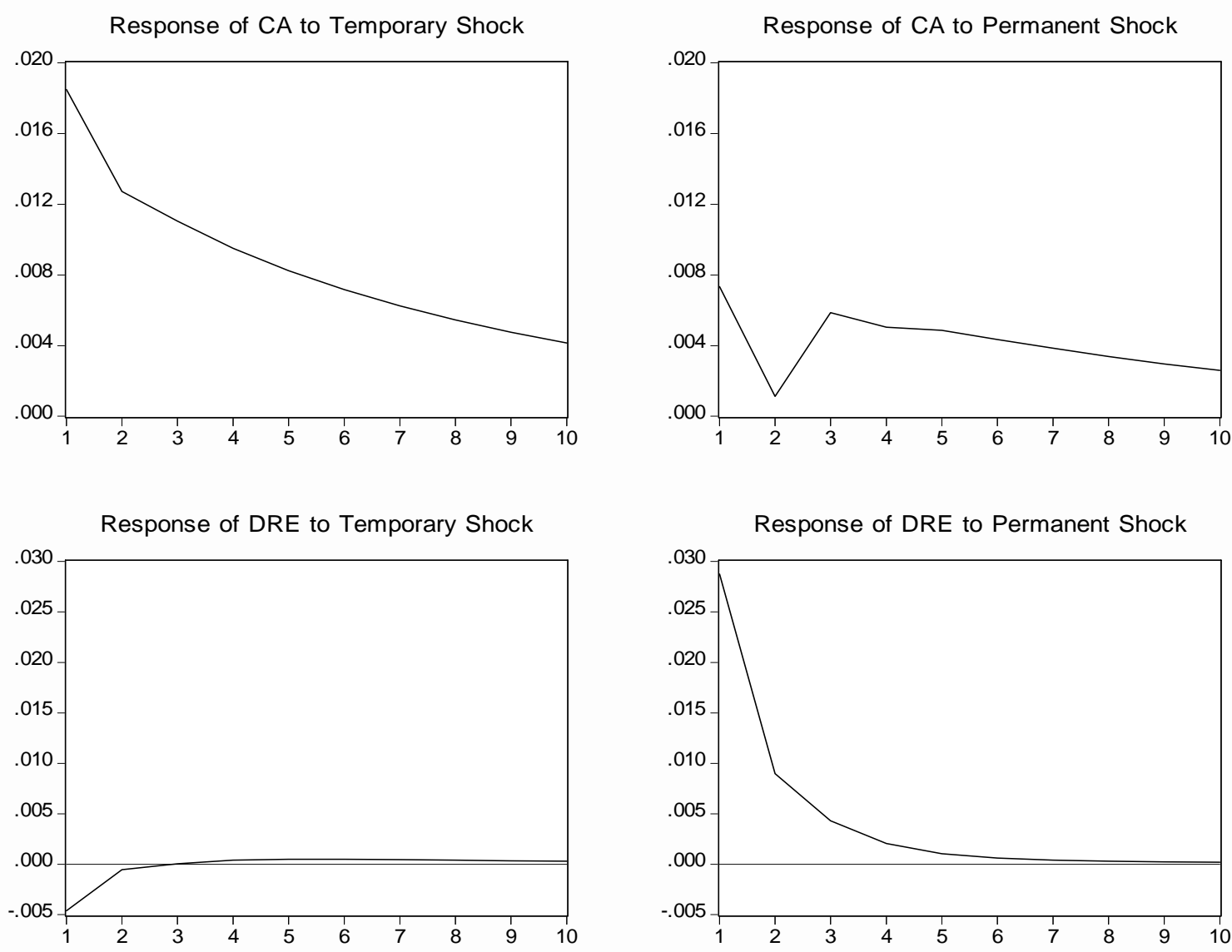
Figure 4. United States: Historical Decomposition
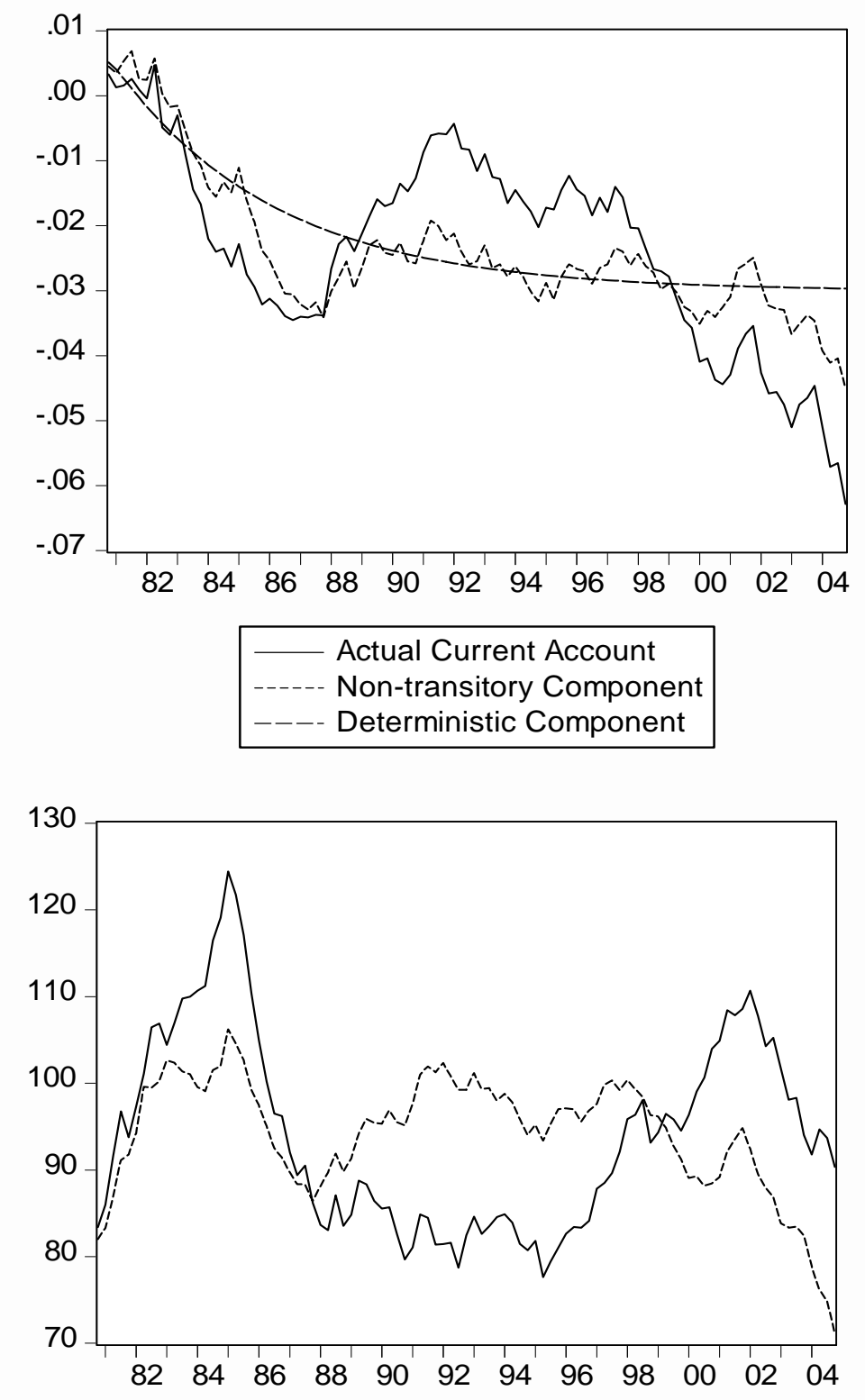

Actual Exchange Rate ----- Non-transitory Component 
Figure 5. Japan: Historical Decomposition
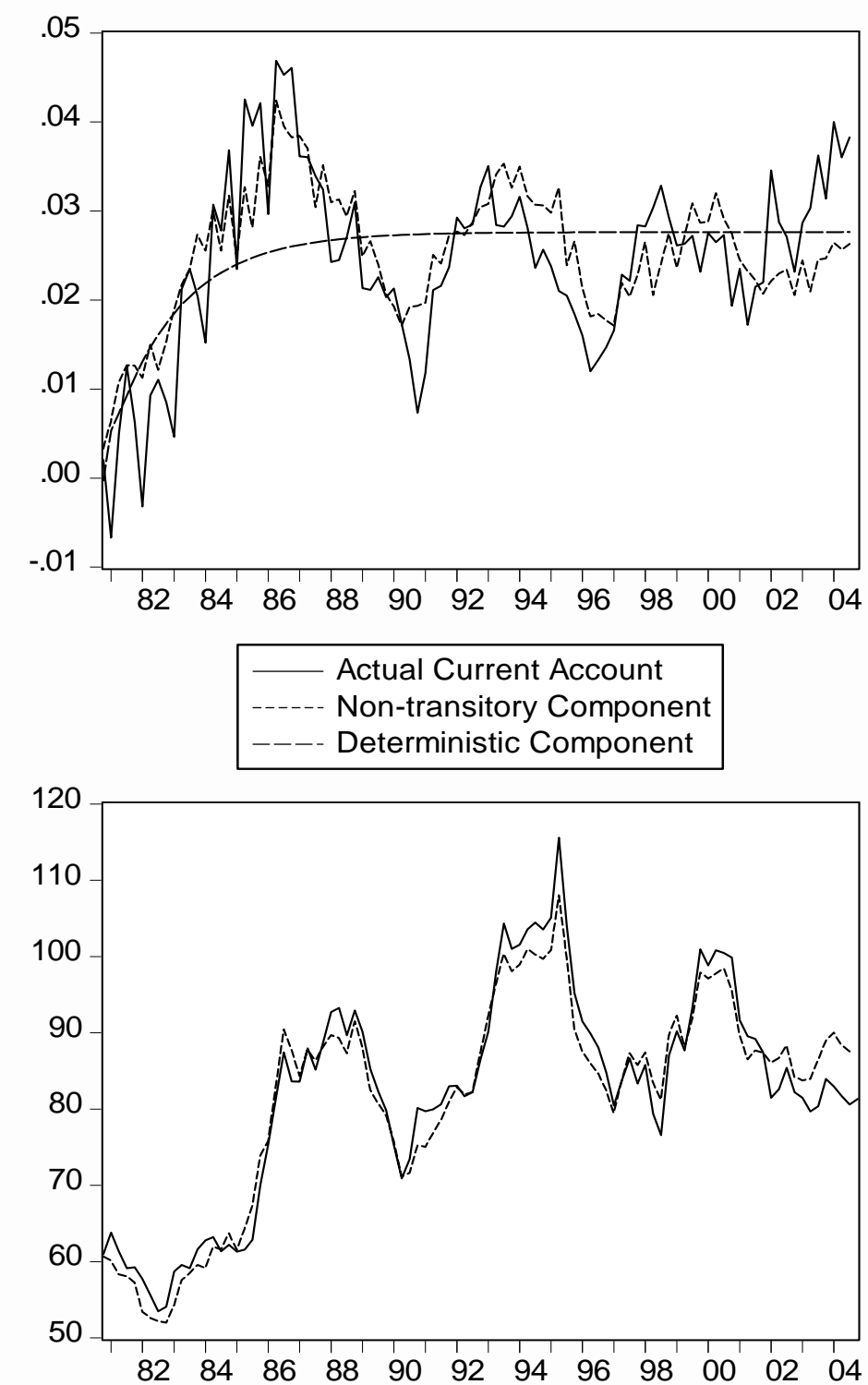

_- Actual Exchange Rate ----- Non-transitory Component 
Figure 6. Euro Area: Historical Decomposition
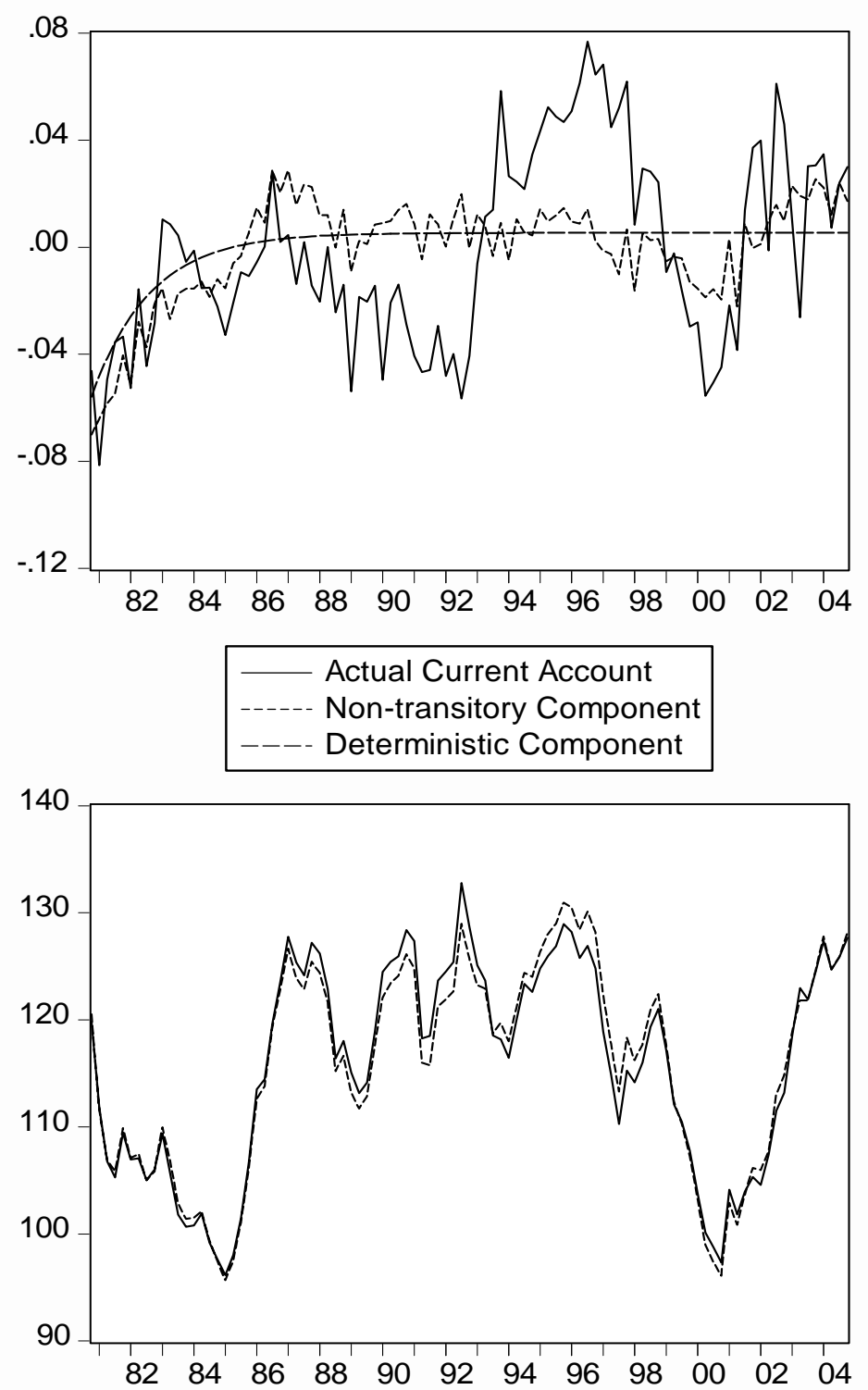

_- Actual Exchange Rate ----- Non-transitory Component 